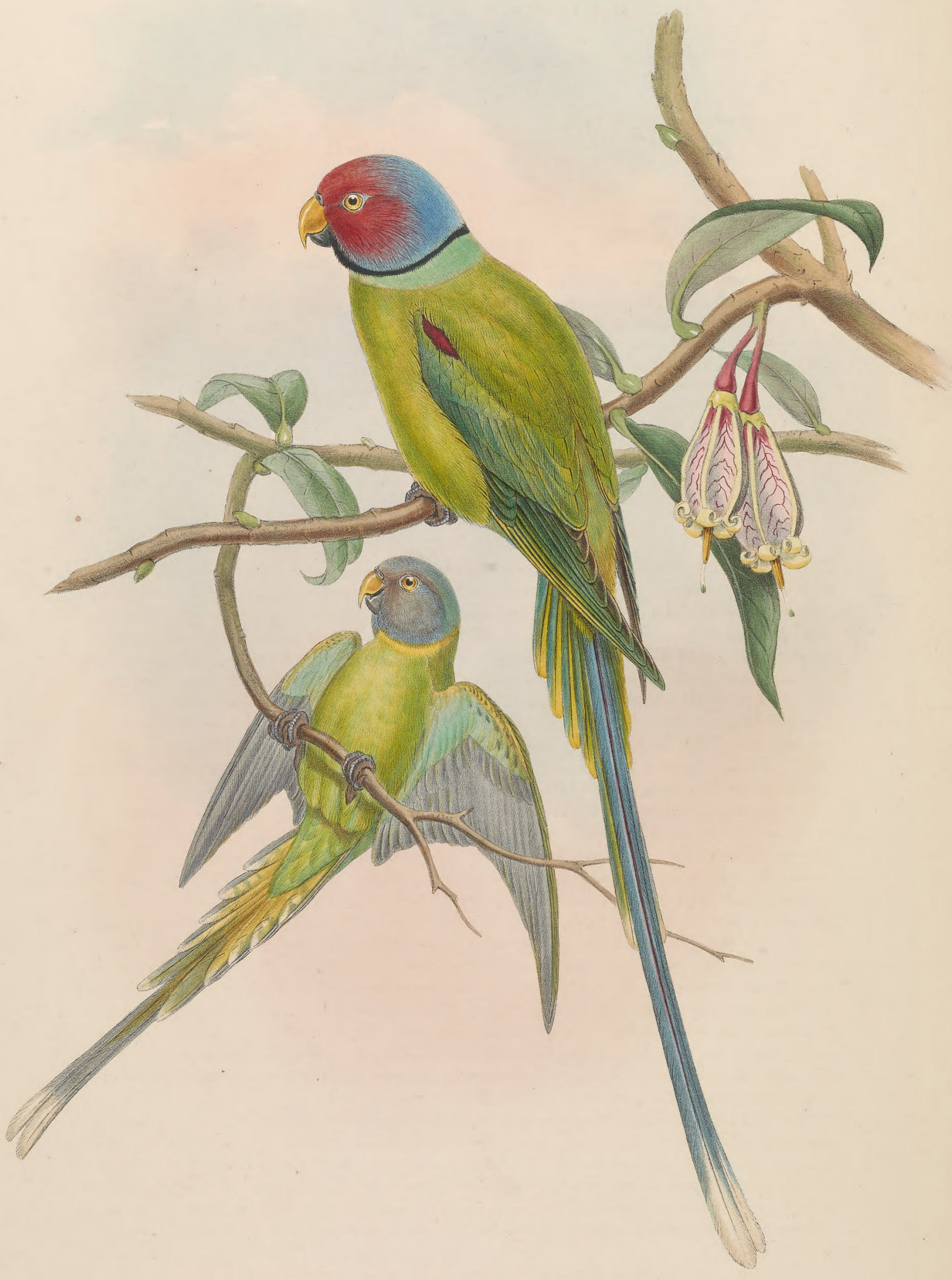




\section{PALAORNIS ROSA.}

Blossom-headed Parrakeet.

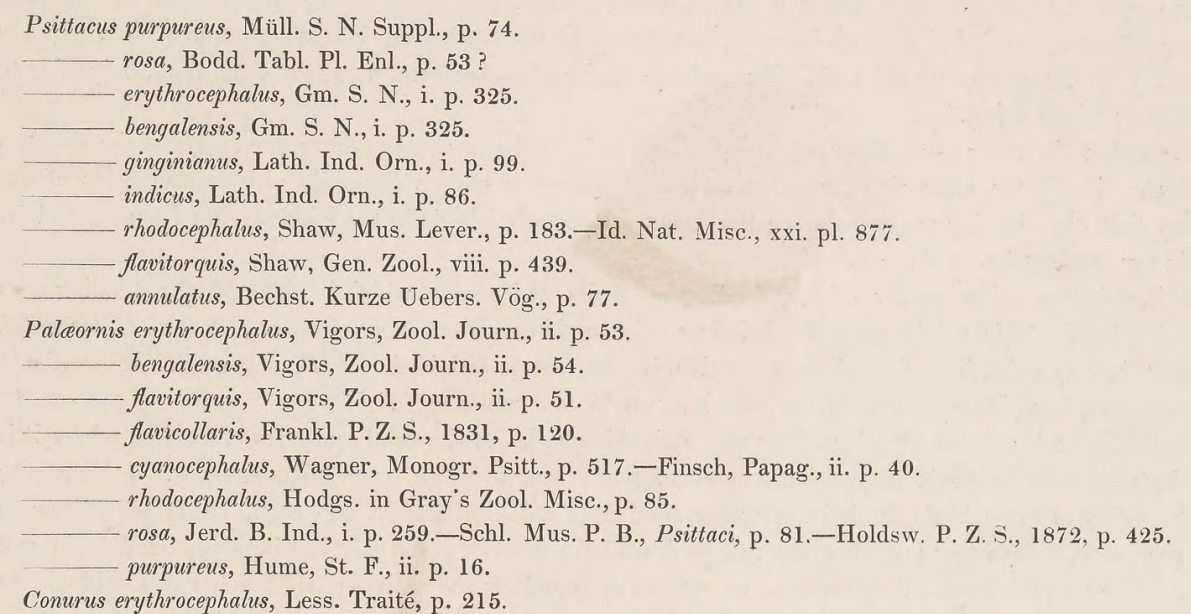

For a long time I have been convinced that two distinct species had been confounded by ornithologists under the title of Palcoornis rosa. The late Mr. Blyth took up the subject for me, and gave me the names for the respective birds, which I then drew for the present work. The plates were long ago printed off with the names assigned to them by Mr. Blyth; and it was not until quite recently, when I was working out the synonymy, that I came to the conclusion that my friend was not quite right in the titles of the species. In deference to his well-known judgment I have retained them; but it seems to me that the Indian bird should bear the name of $P$. cyanocephala, of Linnæus, founded on 'La Perruche à teste bleue,' of Brisson (Orn., iv. p. 359, pl. xix. f. 2); while the Burmese bird should rightly be called P. rosa, of Boddaert, founded on plate 888 of the 'Planches Enluminées' and Edwards's 'Rose-headed Ring-Parrakeet' (Glean., v. p. 47, pl. 233). With the exception that probably the names of the species will some day require transposition, I believe that the above synonymy will be found accurate and complete.

Whatever names, however, the two birds may ultimately bear, there can be no doubt that they constitute two distinct species; and I am glad to see that this view has been adopted by Mr. Hume. I subjoin the notes recently published by this gentleman, as they exactly define the differences between $\boldsymbol{P}$. rosa ( $\boldsymbol{P}$. purpureus of Hume) and $P$. cyanocephala ( $P$. bengalensis of Hume). He writes:- "Here, according to my views, Dr. Finsch has combined two distinct species. In the one, which I will call $P$. purpureus (Müll.), which is from Ceylon, Southern, Central, the whole of Northern and Western India, and the Himalayas, as far east, at any rate, as the Dhoon, the adult males have a brighter and more crimson wing-spot than in the other; the under wing-coverts and axillaries are glaucous or verditer blue; the head peach-bloom, or, more correctly, a beautiful red shaded with blue on the occiput, nape, and more faintly so on the cheeks; and black mandibular stripes continued as a collar round the back of the neck. The adult females want the black mandibular stripe and collar, and the red wing-spot, and have the whole top, back, and sides of the head a sort of lilac, browner generally on the sides, and with a more or less distinct yellow ring round the neck, at the termination of the lilac cap. In both sexes the upper mandible is yellow, varying from a waxto a somewhat orange-yellow, and lower mandible black or dusky."

"The quite young birds have the whole top and back of the head dull green, rather darker than the back, contrasting with the latter and indicating where the coloured cap will ultimately be ; both mandibles are in these pure wax-yellow; and eren the males want the red wing-spot. At an older stage the young males are like the adult females; at a little later stage the lilac of the head becomes slightly darker, a ruddy tinge begins to show out at the base of some of the feathers, a few of the feathers of the forehead change to the same colonr as in the adult male, and the place of the red wing-spot is marked by conspicuous orange tippings to the feathers."

In this same article in 'Stray Feathers' Mr. Hume gives Captain Hutton's notes on the young bird as follows:- "The nestling bird has a pale yellow beak, but neither wing-spot nor coloured head; it is 
uniformly of a pale yellowish green, with a still lighter-coloured ring round the neck; and the upper surface of the tail exhibits a little blue. In the second year the head becomes of a fine bluish cast, with a yellow collar round the neck, when it becomes the $P$. cyanocephalus; and in the third year the head of the male becomes a most beautiful rich peach-blossom, shading off to the black ring into a soft azure blue. In the third year the full plumage of the adult is acquired; and each subsequent year, for some time, only adds to its richness of colouring."

Dr. Jerdon observes :- " It frequents jungly districts in preference to the more open parts of the country, but occurs in all the more richly wooded cultivated districts; and it generally visits those parts of the country that are tolerably wooded during the rains. It usually breeds in the jungles; but I have found its nest in my own garden at Sangor."

"It has similar habits to the others, feeding on fruits and grains, which it picks off the standing corn or, in the stubble-fields, off the ground. It is less noisy, and has a much more pleasant call, than $\boldsymbol{P}$. torquatus. Its flight is very swift, indeed much more so than in the last-named bird and $P$. alexandri. It breeds in holes of trees, from December to March, and has usually four white eggs."

Mr. Holdsworth writes :- "I have only met with this species in the southern parts of Ceylon, where it is very destructive to the grain crops; but it is also found at times on the lower hills generally. I have seen a flock of fifty of these birds fly down one after another to a field of paddy, and each, biting off an ear of the greell corn, return to a neighbouring tree to devour the plunder; and this has been repeated again ane again. The three species of Palcoornis are constantly caged by the natives; and few native dwellings are without one or other of these favourite pets." Mr. Vincent Legge, also writing from Ceylon, says:- " $P$. rosa is numerous from the low country up to the highest part of the Marowa-Korle, being found in the greatest numbers in the intermediate hills."

The large figure in the Plate is of the size of life. 


\section{$2 \mathrm{BHL}$ Biodiversity Heritage Library}

Gould, John. 1874. "Blossom-headed Parrakeet, Palaeornis rosa [PI. 2]." The Birds of Asia 6(XXVI), -. https://doi.org/10.5962/p.323422.

View This Item Online: https://www.biodiversitylibrary.org/item/122488

DOI: https://doi.org/10.5962/p.323422

Permalink: https://www.biodiversitylibrary.org/partpdf/323422

\section{Holding Institution}

Smithsonian Libraries

\section{Sponsored by}

Smithsonian Institution Libraries

\section{Copyright \& Reuse}

Copyright Status: Not in copyright

This document was created from content at the Biodiversity Heritage Library, the world's largest open access digital library for biodiversity literature and archives. Visit BHL at https://www.biodiversitylibrary.org. 